\title{
ПРОБЛЕМЫ ФОРМИРОВАНИЯ СИСТЕМЫ ПРЕДУПРЕЖДЕНИЯ ПРЕСТУПНОСТИ В РОССИИ
}

\author{
Гончарова М.В.
}

Аннотация: В статье представлень криминологические конщепџии противодействия преступности, на основе анализа которых дается оценка современного состояния предупреждения преступности, выделены проблемы и недостатки такой деятельности в Российской Федерации. Особенность предметного исследования заключается в изучении концепџии воздействия на причины преступлений с последующим ее нормативным закреплением. Отказ от преступного поведения может быть обусловлен не только собственным решением преступника, но и профилактическим воздействием, оказываемым на человека, - общесочиального и специально-криминологического характера. Методологическую основу исследования составляет следующая группа методов: сравнительный, системный, аналитический, структурно-функииональный, прогностический, метод контентанализа, моделирование. Особенность исследовательского подхода заключена в концептуальном изучении системы профилактики преступности. В специально-криминологическом значении профилактическое воздействие направлено на непосредственный отказ от преступного поведения у лии, совершивших преступление, как однократно, так и повторно. Поддержка бывших осужденных после освобождения, на постпенитернциарной стадии контрольными и соииально-адаптационными мерами позволит закрепить достигнутые результаты исправительного воздействия.

Ключевые слова: Система, предупреждение, меры, конщепџия, преступность, реализация, формирование, уголовные наказания, исправивщиеся, борьба.

В последнее десятилетие возросло значение научного подхода к определению направлений развития и управления социальными процессами в сфере противодействия преступности. Однако провозглашаемые приоритеты часто не соответствуют складывающимся реалиям, определяемым уровнем социально-экономического и духовного развития общества, а также состоянием криминальной ситуации. Продолжаемые кризисные явления привели к тому, что теория и практика правоприменительной деятельности развиваются стихийно и практически независимо друг от друга. Предупреждение преступности в науке, существуя в виде различных теоретических схем, и такая деятельность в реальных условиях не всегда согласуются между собой. Такое расхождение породило несогласованность между принципиальными теоретическими положениями и применяемыми методами воздействия на преступность, что в свою очередь приводит 
с одной стороны к чрезмерной либерализации, а с другой - дезорганизует деятельность по предупреждению преступности.

Построение системы предупреждения преступности предполагает, исходя из глубокого познания факторов, ее детерминирующих, разработку комплекса оптимальных и скоординированных направлений и мер воздействия на нее. В России формирование этой системы находится в начальной стадии. Если на государственном уровне предпринимаются определенные шаги по ее созданию, носящие в основном характер организационных решений, то предупредительная деятельность «на местах», непосредственно среди населения, в частности индивидуальная профилактика, носит формальный характер. Профилактический потенциал ослаблен, социальный контроль над преступностью не эффективен. Нерешенными остаются вопросы, в отношении кого она должна осуществляться, кто ее должен реализовывать и в каких пределах, не определены направления, формы и методы. Что касается «исполнителей», то предупреждение преступлений закреплено за достаточным количеством субъектов, однако в числе других их функций, более значимых в результативной оценке деятельности, профилактике отводится формальное внимание. В этой связи удивительно современно звучат слова П.Я. Чаадаева о том, что в России «ни у кого нет определенного круга действий, нет ни на что добрых навыков, ни для чего твердых правил < ..> ничего устойчивого, ничего постоянного, все живут без убеждений, без правил даже и в повседневных мелочах <..> Прежние идеи выметаются новыми, потому что последние не вырастают из первых, а появляются откуда-то извне...» [1].

Кроме того, ни одно десятилетие велась дискуссия о необходимости принятия закона о профилактике, которая разгорелась с новой силой после разработки и представления проекта Федерального закона «Об основах системы профилактики правонарушений в Российской Федерации». Полагаем, что такой нормативный правовой акт необходим. Требуется и создание органа, специализирующегося на осуществлении профилактики преступности.

В основу построения системы профилактики преступности должна быть положена концепция воздействия на ее причины с последующим ее нормативным закреплением. В теории криминологии существует не так много моделей таких концепций. Обобщая научные представления о них, можно выделить три концепции противодействия преступности.

Первая концепция представляет собой своеобразную войну с преступностью, а точнее - c преступниками. Такая концепция обычно практикуется в тоталитарных государствах. К наиболее характерным методам ведения этой «войны» относятся: практика показательных казней, введения военного режима с комендантским часом и расстрелами на месте без суда и следствия, телесных наказаний, ужесточения уголовной ответственности за совершение незначительных проступков и инакомыслие [2]. Такая концепция воздействия на преступность в различные периоды истории имела место и в нашей стране.

Концепция войны с преступностью не укладывается в прогрессивные гуманистические начала существования демократических государств, где ценен каждый член общества, пусть даже «оступившийся», и при грамотном применении к нему мер уголовного, политического, экономического, социального, идеологического и исправительного характера, способного вернуться в общество полноценным членом.

Вторая концепция появилась не так давно и отражает нестандартные подходы к проблеме противодействия преступности. Отдельные криминологи видят в деятельности по контролю над преступностью индустрию. Объясняя это тем, что, с одной стороны, она является источником работы и прибыли (правоохранительные органы, места лишения свободы), с другой - обеспечивает контроль над теми, кто является источником опасности для общества (профилактика преступлений, исполнение наказаний, административный надзор и т.д.), в котором существует. По сравнению с другими эта индустрия занимает 
постоянную привилегированную позицию - преступность и преступники, ее продуцирующие, вечны, также как и стремление обезопасить себя и нести по этому поводу определенные издержки (налоги, охранно-контрольные системы).

Однако, как и всякая экономически выгодная, индустрия контроля над преступностью должна быть должным образом организована, управляема, сбалансирована и обеспечиваема, чтобы эффективно решать поставленные перед ней задачи, гарантировать безопасность современного общества [3].

Третья концепция, традиционная, исходит из того, что предупреждение преступности, являясь наиболее гуманным средством поддержания правопорядка и обеспечения безопасности общества и личности, наряду с защитой от преступных посягательств, удерживает неустойчивых членов общества от совершения преступлений, избавляя от практически неизбежного наступления уголовного наказания [4].

Эта концепция опирается не на «машину» подавления, а на системную перестройку общества, приоритетных начал его существования, функционирования и развития на основе нравственности, справедливости, честности, гуманизма, духовности. В таком обществе есть все предпосылки для контроля над преступностью и ее удержания в допустимых пределах. Система пресечения преступлений, карательные меры не отвергаются, а являются скорее исключением, чем основным средством. Стремление к этому идеалу пока находит воплощение лишь в теории криминологической профилактики преступлений. Полагаем, что при построении системы профилактики следует стремиться к такому ее окончательному варианту.

Мы не согласны с точкой зрения, что при выборе стратегии борьбы с преступностью предпочтение должно отдаваться предупреждению преступности, как указывают некоторые криминологи [5]. В этой связи справедливым видится высказывание М.М. Бабаева и М.С. Крутера о том, что определять в современных условиях предупреждение преступности основным направлением ее противодействия, значит отры- ваться от действительности. Оценивая состояние профилактической деятельности и современные возможности криминала, становится очевидным неравенстово сил. «Сложные, противоречивые, способные развиваться по мало предсказуемым сценариям процессы современной преступности могут быть «обузданы» только на основе осуществления гибкой, готовой ответить на «любые» вызовы криминала государственной политики борьбы с преступностью. В зависимости от характера складывающихся ситуаций, на одном этапе приоритет может быть отдан именно профилактике. В другом на первое место может выйти деятельность правоохранительных органов, осуществляющих иные функции (уголовный розыск, следствие), так как обстоятельства ставят перед обществом в качестве наиболее актуальных задачи другого характера» [6].

Было бы неправильным недооценивать значение уголовно-правовых средств предупреждения преступности. Уголовная политика, основываясь на конституционных предписаниях, формирует деятельность государства в сфере противодействия преступности. Кроме того, одна из целей уголовного наказания - предупреждение совершения новых преступлений. Отдавать предпочтение уголовно-правовым мерам также неверно, поскольку оказывая репрессивное воздействие непосредственно на личность преступника, они не устраняют причины и условия, порождающие совершение преступлений, что подтверждается качественным состоянием преступности, и теми негативными тенденциями, которые выявляются в ее характеристике (например, рост рецидивной преступности), и «ценой», которую вынуждено платить общество за исправление преступников и предупреждение преступности. Мало способствует уголовное наказание и восстановлению социальной справедливости. Поэтому к преступникам целесообразнее применять комплекс профилактических мероприятий, включая и уголовно-правовые.

Как известно, криминогенным потенциалом для преступности обладает пенитенциарная система, а именно места лишения свободы, которые ее 
Реализация этого положения на практике

продуцируют. «Фабрикой» преступности называют их зарубежные криминологи. В связи с этим пенитенциарную и постпенитенциарную профилактику выделяют в качестве неотъемлемого элемента системы профилактики преступлений в целом.

Отказ от преступного поведения может быть обусловлен не только собственным решением преступника, но и профилактическим воздействием, оказываемым на человека, - общесоциального и специально-криминологического характера.

Общесоциальное воздействие осуществляется различными государственными и общественными институтами в политической, экономикой, социальной, нравственно-духовной сферах жизни; оно касается улучшения условий труда и досуга граждан, повышения уровня и устройства жизни, других позитивных изменений в обществе. Такое воздействие, распространяясь на все общество, стимулирует отказ от выбора преступного образа жизни.

В специально-криминологическом значении профилактическое воздействие направлено на непосредственный отказ от преступного поведения у лиц, совершивших преступление, как однократно, так и повторно. На достижение этой цели направлена пенитенциарная и постпенитенциарная профилактика. При этом формирование правомерного поведения не является одномоментным актом, происходит постепенно, поэтому, чем раньше начнется ресоциализация таких лиц, тем вероятнее наступит отказ от преступного поведения. Оптимальное время для начала таких мероприятий - в процессе отбывания уголовного наказания. Поддержка бывших осужденных после освобождения, на постпенитернциарной стадии контрольными и социально-адаптационными мерами позволит закрепить достигнутые результаты исправительного воздействия. весьма сложна, поскольку на сегодняшний день государственных организаций федерального уровня, социально-адаптационных служб, занимающихся трудовым и бытовым устройством бывших осужденных, в стране нет. Они есть только на региональном уровне (Центры социальной адаптации) и созданы, можно сказать, на энтузиазме администраций отдельных исправительных учреждений с задействованием общественных и благотворительных организаций, бывших сотрудников уголовно-исполнительной системы, служб занятости населения, миграционных органов, образования и социальной защиты населения, а также лиц, отбывших уголовные наказания и исправившихся. Их деятельность распространяется на оказание помощи в бытовом и трудовом устройстве, в профессиональном обучении и переобучении, получении трудовой квалификации, а также в предоставлении медицинских услуг.

Эффективное предупреждение преступлений требует использования последних научных достижений в различных сферах, особенно в сфере психологии, которая способна дать ответ на вопрос, почему люди совершают преступления, тем самым определив факторы, воздействуя на которые, можно достичь наибольшей результативности профилактической деятельности [7].

Современный этап формирования системы предупреждения преступности характеризуется целым рядом трудностей, связанных с несовершенством уголовной политики, законодательства, дисбалансом федеральной и региональной политики в сфере противодействия преступности, недооценкой личности преступника, значимости антикриминогенных факторов и криминального потенциала факторов, детерминирующих преступления.

\section{Библиография:}

1. Чаадаев П.Я. Философские письма. Сочинения. М.: Правда, 1989. С. 19-20.

2. Иншаков С.М. Системное воздействие на преступность в вооруженных силах России: Дис. ... д-ра юрид. наук. М., 1997. С. 123-124. 
3. Кристи Н. Борьба с преступностью - доходная индустрия // Уголовно-исполнительная система: право, экономика, управление. - 2011. - № 5. С. 8.

4. Блувштейн Ю.Д., Зырин М.Н., Романов В.В. Профилактика преступлений. Минск, 1986. С. 9-10.

5. Пинкевич Т.В. Криминологические и уголовно-правовые основы борьбы с экономической преступностью: Дис. ... д-ра юрид наук. М., 2002. С. 262-263.

6. Бабаев М.М., Крутер М.С. Молодежная преступность. М., 2006. С. 300.

7. Пастушеня А.Н. Криминогенная сущность личности преступника (психологический аспект). Дис. ... д-ра психологич. наук. М., 2000. С. 441-442.

\section{References (transliterated):}

1. Chaadaev P.Ya. Filosofskie pis'ma. Sochineniya. M.: Pravda, 1989. S. 19-20.

2. Inshakov S.M. Sistemnoe vozdeistvie na prestupnost' v vooruzhennykh silakh Rossii: Dis. ... d-ra yurid. nauk. M., 1997. S. 123-124.

3. Kristi N. Bor'ba s prestupnost'yu - dokhodnaya industriya // Ugolovno-ispolnitel'naya sistema: pravo, ekonomika, upravlenie. - 2011. - № 5. S. 8.

4. Bluvshtein Yu.D., Zyrin M.N., Romanov V.V. Profilaktika prestuplenii. Minsk, 1986. S. 9-10.

5. Pinkevich T.V. Kriminologicheskie i ugolovno-pravovye osnovy bor'by s ekonomicheskoi prestupnost'yu: Dis. ... d-ra yurid nauk. M., 2002. S. 262-263.

6. Babaev M.M., Kruter M.S. Molodezhnaya prestupnost'. M., 2006. S. 300.

7. Pastushenya A.N. Kriminogennaya sushchnost' lichnosti prestupnika (psikhologicheskii aspekt). Dis. ... d-ra psikhologich. nauk. M., 2000. S. 441-442. 